\title{
ONOMÁVEIN
}

Journal of linguistics, philology and translation

\section{Indications of lexical-semantic changes in the Arabisms of the Kingdom of Granada (1493-1612): the lexical competition between almádena and martillo*}

\section{Inmaculada González Sopeña}

Universidad de Granada

España

\section{(c) $\odot$}

Inmaculada González Sopeña: Departamento de Lengua Española, Facultad de Filosofía y Letras, Universidad de Granada, España. | E-mail: isopena@ugr.es 


\section{Abstract}

The objective of the present study is to analyze a couple of lexical items formed by an Arabism and a Romance voice (almádena and martillo) through a corpus of documents linked to the ancient Kingdom of Granada (i.e. the current provinces of Málaga, Almería and Grana$\mathrm{da}$ ) in the late 15th century to 17th century. That documentation includes different types of texts as the correspondence of Hernando de Zafra or texts linked to the building construction at that time. Due to the historical, political, social and religious peculiarities of the Kingdom of Granada there is a persistence of lexicon of Arab origin over the above two centuries with regard to other Spanish-speaking territories. However, Arabic loanwords in Spanish lexicon are subjected to specialization processes or semantic restrictions, as exemplified in the case of almádena. This voice lexically competed with the Romance voice martillo, but, finally, the first one suffered a process of semantic restriction and it is actually cornered in some dialectal areas.

Keywords: lexical-semantic changes; Arabisms, Kingdom of Granada; history of Spanish lexicon; tools and construction.

* The present study is part of the research project with reference FFI2017-83400-P (MINEO/AEI/ FEDER, UE). Also, it is framed in the University of Granada FPU Scholarships Program (2015-2019). 


\section{Introduction}

The object of study of this article focuses on the analysis of a lexical couple formed by an Arabism and a Romance voice: almádena and martillo. In order to do that, a corpus of documents attached to the ancient Kingdom of Granada has been developed. These documents are linked to the municipal and administrative life from the late 15th century to the 17th century.

The starting hypothesis is that due to the historical, political, social and religious peculiarities of the Kingdom of Granada there is a persistence of lexicon of Arab origin over the above two centuries with regard to other Spanish-speaking territories.

The temporal line that goes from the late 15th century to the 17th century is justified by the great historical and political convulsions that have an immediate linguistic reflection in Castilian. In 1492, the ancient Nasrid Kingdom is finally conquered by the Spaniards and became part of other territories under the rule of the Catholic Monarchs. Furthermore, the colonization of America and the publication of the Gramática of Nebrija drew a favorable scenario that led to the standardization of Spanish during these centuries (Giménez Eguíbar, 2011: 59-61).

Traditionally, lexical-semantic changes encompass both phenomena of neology and lexical loss (Walsh, 1967; Maíllo, 1983; Dworkin, 2004, 2006, 2012; Álvarez de Miranda, 2009: 135; Giménez Eguíbar, 2015, 2016). The loss of Arabisms is mentioned in many of the monographs dedicated to the history of the Spanish language (Cano Aguilar, 2004; Lapesa, 1991). However, Dworkin asserts that "rivalry (quasi-) synonyms of Arab origin and Romance ones is another issue of diachronic lexicology that deserves a case study" (2011: 160).

Following that idea, the present study analyzes the lexical-semantic changes of the Arabism almádena, which is present in the corpus of the Kingdom of Granada (1493-1612). Almádena is an Arabism belatedly introduced into Castilian Spanish that was finally restricted to the specialized language of construction, such as the cases of acibar-aloe, aceche-caparrosa, alarguez-aspátalo, alfóstigo-pistacho in other areas (Fasla, 2000: 83).

The article is structured in the following sections. First, we offer a brief background about the history of the Arabisms in Spanish language in relation to the linguistic attitudes that they had; the theoretical framework is developed in section three. Then, the corpus of the Kingdom of Granada is described as the base corpus of this study; also the control corpus consulted will be set. Section fifth offers the case study of almádena and martillo. Last, we establish the final conclusions.

\section{Background}

There is a major legacy of Arab origin in Spain in both culture and language. From the year 711, with the first Muslim invasion, composed mostly by Berbers, every aspect of life in the Iberian Peninsula began to change (Steiger, 1967: 93-95). This Arabic presence produced many changes 
in all areas, including the linguistic one. It is possible to see this influence in many Arabisms that have covered all fields of human life: science, construction, institutions, customs, business, urban planning, housing, domestic life, agriculture, foods, plants, flowers, fruits, minerals, music, colors and so on (Giménez Eguíbar, 2011: 36).

In that way, an intense language contact for more than seven centuries started between all varieties of Romance languages and the different varieties of the Arabic ones, and thus it was setting the basis for what is known as Hispanoarabic or Andalusi (Corriente, 1977) ${ }^{1}$. The Arabisms entering in Castilian at this early stage would come from that Hispanoarabic and not from the classical Arabic. This lexicon was introduced through Mozarabs firstly ${ }^{2}$ and through the contact between the Moorish and the Castilian conquerors since the 13th century (Steiger, 1932; Corriente, 2004).

Arabic was used in the written language for massive transmission of their knowledge and culture. As a consequence of their cultural influence, many Arabic loanwords were progressively adopted in the Castilian Romance: "During the period of eight centuries that there existed a Muslim state in the Peninsula, Romance culture and society underwent a significant influence of the prestigious Arabic language and culture. Linguistically, this influence resulted in numerous Arabic lexical borrowings" (Gallego, 2003: 118).

As Christians advanced in their conquest, Hispanoarabic was used less and less and it was finally cornered in the Kingdom of Granada until its final reconquest in 1492 and the final Moorish expulsion in 1609.

\section{Theorical framework}

The pointed hypothesis is that Arabisms were falling into disuse and were gradually replaced by Romance voices or relegated either to a specialized language or to dialectal languages like obsoleted or archaic voices. The reason for this can be found in the strong linguistic conscience $^{3}$ developed during the 16 th century against Arabisms, which falls within the fledgling standardization of Castilian that became a negative social vision to the Arabisms:

1 See the excellent study of the phenomena of diglossia between classical Arabic and colloquial Arabic at the Peninsula in Gallego (2003).

2 Chronologically, there are three periods of Arabisms incorporations in the northern Hispanorromance variants, as proposed by Dworkin (2012: 101): 1) the earliest were incorporated by bilingual Christians; 2) the second important period was the reconquest (1085-1300); 3) late borrowings (usually technical lexicon) from Mudejars.

3 See Gallego (2003) for the exact linguistic conscience which was developed in the Peninsula during the Middle Age, in which the use of one variety or another was sacralized. 
The language attitudes towards Arabisms in Castilian Spanish must be understood within the framework of language standardization, a process that involves codification, language attitude, prescription and purism, and lexical selection. In this context, the fifteenth and sixteenth centuries are significant periods for the Latinization of Castilian lexis and the consequent loss of many Arabisms4 (Giménez Eguíbar, 2016: 377).

The close link that occurs between historical changes and lexical changes has been a widely discussed topic in diachronic linguistics (Meillet, 1952; Matoré, 1953; Dubois, 1962; Baldinger, 1985; Lapesa, 1985; García Godoy, 1999, 2012). In the case of the Iberian Peninsula, the marriage of Ferdinand and Isabella (the Catholic Monarchs), the conquest of the Kingdom of Granada and the colonization of America are certainly facts that set the course of Spanish as a language of culture that grows and expands (Asensio, 1960: 412-413). In addition to the standardization of Castilian, the phenomenon of variation and lexical loss around Arabisms is also related to the new discursive tradition that begins to take shape in the 16th century: Renaissance humanism. This new cultural horizon brought with it an unfavorable perception toward the voices of Arab origin, which are formed in linguistic consciousness as not prestigious uses linked to a previous discursive tradition and to another religion: "During the Low Middle Age, the introduction of new speeches from Europe through the Kingdom of Aragon gives rise to new forms of scientific and technical knowledge. The new organization of knowledge involves a semantic specialization and new terminology" (Giménez Eguíbar, 2015: 1422).

In this sense, the presence of numerous Arabisms in Castilian presumed a distance within the Renaissance ideal of the 16th century: "[...] the abundance of Arabic vocabulary that significantly separated Castilian from the humanistic aspiration inherent in the codification of Castilian Spanish" (Giménez-Eguíbar, 2016: 347).

The testimonies and statements from various authorities, political and linguistic ones, discover explicit measures against Muslim ways of life since the conquest of the Kingdom of Granada and throughout the 16th century. These measures affected the customs, ways of life and the language of the Moorish. Note about the testimony collected in the correspondence of the Count of Tendilla, where the Catholic Monarchs order to burn all Muslim holy books publicly in 1501:

Bien sabeis que por graçia de Nuestro Señor los moros que bevian e moravan en este dicho reino de Granada se convirtieron a nuestra santa fe catolica. E porque en el tienpo que el dicho reino era

4 In Spain, the language codification procedure for Castilian started in 1492 with the Gramática and the Vocabulario Español-Latino written by Nebrija. It is the first step towards the purist and prescriptive attitudes that will be developed in successive grammars and other texts around Arabisms. In addition, the invention of printing set undoubtedly a before and after, as the ability to print books will be used as propaganda regarding the "right" language (Giménez Eguíbar, 2011, 2016). 
poblado de moros tenian muchos libros falsos e de su seta falsa, los quales deven ser quemado en el fuego, por que dellos no aya memoria [... $]^{5}$ (Barrios Aguilera, 2002: 81).

Despite the promised tolerance toward Moorish in the Capitulaciones (1492), as we move into the 16th century, there is going to be an identification of Arabic language as a problem in the cultural and religious assimilation of the Moors or Christians newly converted. Treaties tend to identify everything related to the Muslim world with "the vanquished", "the demon" (Peinado Santallea, 2017: 153), and thereby their language.

At the same time, Greek and Latin neologisms are associated with the Renaissance modernity and replace, where possible, the ancient voices of Arab origin (Giménez Eguíbar, 2011: 41). Since the 13 th century a discourse based on Latin was developed (such as the work of Alfonso $X$ the Learned) which would be continued by the humanists; that discourse consisted on the equating of Castilian to Latin (Gallego, 2003: 12), which directly affected the attitude towards Arabisms.

\section{Methodology: the corpus}

The base corpus for the present study, the corpus of the Kingdom of Granada, is composed by several municipal and administrative documents. The timeline of the documents selected for this study begins in 1493 and ends in 1612. Specifically, we have selected the correspondence of Hernando de Zafra (Royal Secretary) and a set of documents linked to the conservation and restoration of buildings:

- Gila Medina, Lázaro, 2000: Maestros de cantería y albañilería en la Granada moderna según los escribanos de la ciudad, Granada: Ilustre Colegio Notarial de Granada.

- De la Obra Sierra, Juan María, 2011: Correspondencia de Hernando de Zafra, Granada: Universidad de Granada.

- Galera Mendoza, Esther, 2014: Arquitectos y maestros de obras en la Alhambra (siglos XVI-XVIII): artífices de cantería, albañilería yesería y forja, Granada: Comares.

This documentation has received much less attention than it deserves for its great historical-linguistic interest? ${ }^{7}$. It should be said that the documental selection presented here tries

5 "Well you know by the grace of our Lord that the Moors lived in this said Kingdom of Granada and they became into the holy Catholic faith. In the time in that the kingdom was populated by Moors, they had many false books, of their false sect, which must be burned in fire, so that there is no memory of them".

6 The bibliographic key of the documents appears in section 7 (references).

7 It should be said that the computerization of the base corpus is not pursued. We have proceeded to a reading of the texts for the subsequent qualitative analysis of the Arabism almádena. 
to go on in the same line observed in CORDEREGRA (Corpus diacrónico del español del reino de Granada), which is directed by Calderón Campos and García Godoy.

In a first step, the base corpus has allowed to attest almádena in the ancient Nasrid Kingdom with a higher frequency than other territories. Also, the lexicographical information from the Léxico Hispanoamericano (Boyd-Bowman, 2015) has been consulted in order to observe whether this Arabism found a way of expanding those other areas compared with what happens in the Iberian Peninsula.

In order to contrast all the data of that Arabism with its possible lexical substitute martillo, we have used a control corpus: CORDE (Corpus diacrónico del español). The data from this corpus establish a greater use of the Romance voice martillo.

To complete the analysis, it is also necessary to pay attention to the place of these terms (almádena and martillo) in lexicography, the treatment they received, and their inclusion in the current standard language. In order to do that, different resources have been consulted:

- Atlas lingüístico y etnográfico de Andalucía (ALEA), 1961-1973

- Diccionario de la lengua española, Real Academia Española (DLE), 2014

- Diccionario histórico de la lengua española (DHLE), 1960-1996

- Diccionario de arabismos y voces afines al iberorromance, Federico Corriente, 1999

- Diccionario crítico y etimológico del español (DCECH), Joan Corominas y José Antonio Pascual, 1981-1991

- Nuevo tesoro lexicográfico de la lengua española (NTLLE), 2001

- Recopilación de algunos nombres arábigos, Diego de Guadix, 1593

\section{The case study: almádena and martillo}

To begin with, it must be said that martillo is the Spanish patrimonial voice which is dated for the first time in 1280 (CORDE) ${ }^{9}$. Later, the Arabic voice, almádena, was introduced in the Spanish lexicon, dated by 1290 for the first time (DHLE, 1960-1996, S.V.) $)^{10}$.

8 The complete references can be checked in 7.

9 "O non son las mis palabras como fuego. dize el sennor. \& como martillo que quebranta la piedra", Alfonso X the Learned, General estoria. Cuarta parte (CORDE).

10 DCECH, from Corominas, documents for the first time the Arabism almádana approximately in 1300 : "[...] e traían cestos e palas e picos, e azadones e espuertas, e porras e almádanas grandes de fierro". 
On the one hand, almádena is an Arabism defined by the DLE (2014, S.V.) as 'Sledgehammer with a long handle, to break stones'. Etymologically, almádena comes from the Hispanoarabic almátana, and this one may be a contamination of the classical Arabic **mi'dan, which comes from the andalusi páțana, and this one from the Greek patáne 'utensil', 'jalopy' (Corriente, 1999, s.v.). On the other hand, the word martillo is also collected by the DLE (2014, s.v.) with many meanings. From all of them, the first one is comparable to the Arabism almádena: 'Percussion tool consists of a head, usually ironed, and a handle, usually wooded'11 and its etymology comes from the Late Latin martellus.

The treatment of almádena in lexicography has been extensive ${ }^{12}$. However, we highlight here the definition provided by Guadix ${ }^{13}$ (1593) S.v. almádana, which is very rich in details and its meaning is directly related to the meaning of martillo:

Llaman en algunas partes d'España a una porra o cierta forma de martillo o maço de hierro muy pesado, para en cosas donde se requiere gran golpe [...] almatana significará la matana, i.., la dicha porra o martillón; y, corrompido, dizen almádana. En Italia la llaman maça de ferro y maço de ferro $^{14}$ (Guadix, 2005 [1593]: 285).

Furthermore, it is possible to check a few American examples of almádena from the Léxico Hispanoamericano during the 16th and the 17th centuries that would confirm the lexical expansion of that term:

1560, Nueva Granada: hechura de una almádena [ACP 321]

1571, Arequipa: arrancando el adove le davan con una almádena encima, y saltava una costra de piedra delgada que tenía [RPD 191]

11 This definition seems similar to the one offered by DLE (1852) s.v. almádana: 'Instrument similar to a pounder, whose head is ironed, equally thick and flat on both ends, which is inserted in a wooden handle quite long, and serves to break stones'.

12 The omnipresence of almádana from Nebrija's vocabulary (1495) is observed while almádena appears since Covarrubias (1611). In the first edition of Autoridades (1726), the correct term is almádana. In summary, it appears that the meaning of almádena has been collected in the great lexicographical repertoire s.v. almádana, and only in the late 19th century does the lexical entry change from almádana into almádena.

13 Diego de Guadix composed his Recopilación de algunos nombres arábigos which was published in 1593. Guadix's position is complex as he moves between admiration and repudiation towards Arabisms. He admires the great Islamic culture but rejects the "algarabía" and everything that has to do with the Muslim religion. This is a recopilation of Arabisms that at the same time are prescribed in its use in favor of other romance and Latin terms (Giménez Eguíbar and Wasserman Soler, 2011).

14 'In some parts of Spain, they say 'a truncheon' or 'some kind of hammer', very heavy, used in things that require a great knock [...] almatana means 'the truncheon' or 'big hammer'; and corrupted, almádana. In Italy it is called maça/o de ferro". The underline is mine. 
1608, Ciudad de Guatemala: 7 barretas, 2 almadenetas con 2 planchas y cinchos y una almádana de ojo [GTA 156A, 3V]

1643, Nueva Vizcaya (México): una almádana que sirve de yunque, con su macho de yerro y martillo de fragua [AHP 23, 1059].

The treatment of the voice martillo through the lexicography is tracked from Nebrija (1495) and is picked up by almost all the Golden Age lexicographers.

Now consider the cases of almádena from the base corpus of the Kingdom of Granada:

1493, HernandoZafra, p. 145: Ay treynta o quarenta almadauas ${ }^{15}$.

1494, HernandoZafra, p. 200: y para estas cosas se les den media dozena de almadanas e palancas maiores del artyllería de fierro, con algunos picos e camartyllos ${ }^{16}$ grandes.

c. 1508, HernandoZafra, p. 302: Tyene açadones e palas e açadas e palancas e almádanas e camartyllos e martyllos e armas de hierro e çinco barras de hierro e doze barretas de azero ${ }^{17}$.

c. 1508, HernandoZafra, p. 303: Dos almádanas e dos picos ${ }^{18}$.

1611, Can.Alb., p. 108: Señala que en la choza de Álvaro Núñez tiene ciertas herramientas de su oficio -dos barras de hierro, una grande y otra chica, que costaron 100 reales, una almádena, un martillo, un pico, un azadón, etc. ${ }^{19}$

1612, Arquitectos, p. 30: Una almádena y cuatro açadas, dos nudillos y tres picos y dos palas de hierro y cinco cuñas de hierro ${ }^{20}$.

15 The presence of orthographical variation for this Arabism is observed in the documentation of the corpus of the Kingdom of Granada and in the other consulted sources: almádena, almádana, almaina. The variation of the Arabic voice comes from the accentuation, resulting in two variants; however, both emphases are possible in Arabic. For further information about the controversy about the stress between almadana, almádana and almádena see DCECH, s.v. Altering the vowel timbre is common phenomenon in Hispanoarabic, and in its extension, in the Romance, with a result of vowel dissimilation in this case (i.e., two equal vowels in one word in close contact become different ones: a/e): almádana/almádena. In English, the example can be traduced as: "there are thirty or forty sledgehammers".

16 "And for those things they are given half dozen of sledgehammers, iron artillery levers, with some picks and camartillos". The voice camartillo refers to a two-pointed pick, as it is observed in a graphic document entitled Diseños de las erramientas del nuevo camino de Andalucía (Archivo General de Simancas, MPD, 68, 110).

17 "He has hoes, shovels [...] and sledgehammers, and hammers, and iron weapons and five iron bars and twelve steel bars".

18 "Two sledgehammers and two picks".

19 "He points out that in the hut of Álvaro Núñez he has certain tools of his trade -two iron bars, one large and one small, that cost 100 r., a sledgehammer, a hammer, a pick and son on".

20 "One sledgehammer, four hoes and three picks and two iron shovels and five iron wedges". 
In the third and the fifth examples almádena and martillo seem to be different tools, as it can be deduced for the juxtaposition. We can establish that almádena is a specialized voice of a class or a specific type of hammer (martillo). The definition provided by Guadix (1593) where he talks about "some kind" of martillo seems to corroborate this statement.

Now look at the data offered by CORDE (table 1) for both terms, in the studied chronology, in which the recession in the use of the Arab voice could be seen:

\begin{tabular}{ll} 
TABLE 1 & \\
\hline CORDE (1492-1700) & FREQUENCY \\
\hline Almádena, almádana & 8 occurrences \\
\hline Martillo & 659 occurrences \\
\hline
\end{tabular}

As the data indicates, there is a large difference between the uses of the two words. Documentation of almádena is very sparse. This Arabism suffers a kind of semantic specialization like a tool similar to a hammer (martillo) or as a class of hammer, as it is shown in the cases of the corpus of the Kingdom of Granada.

Consider then one case of almádena found in the CORDE database which is important:

1583, Vid. Loyola: Mas estas mismas palabras eran muy llenas de dotrina y espíritu de Dios, y para los coraçones empedernidos y obstinados, como un martillo o almadena de hierro, que quebranta las duras piedras ${ }^{21}$.

The example might confirm that almádena and martillo could be treated at one time as synonymous that could have coexisted in the variation due to the fact that the writing said "como un martillo o almadena de hierro". This synonymy would be motivated by the similarity between both objects, that is, a metonymic expansion of the meaning. However, I have not found any older documental examples where both words present the syntactical sequence that puts these terms at the same semantic level. An example from the late 19th, taken from the journal El Imparcial (Madrid), reflects the next popular poem: "Tu música son los golpes / del martillo y la almádana / con que el adusto cantero / tosco granito devasta" (1893)22. That

21 "These same words were full of doctrine and spirit of God, and for the stubborn and obstinate hearts, like a hammer or an iron sledgehammer, which breaks the hard stones".

22 "Your music is the blows / of the hammer and the sledgehammer / with which the dour stonemason / rough granite lifts". 
one could be considered as a case of quasi-synonymy between two voices whose references are very similar.

Also, other modern case of this quasi-synonymy between almádena and martillo can be found in Corpus del español from Mark Davies (2016):

2010, http://grupomurallaroja.blogspot.com/2010_10_18_archive.html: Ellos siempre al síndico lo ponen de esos huesos colorados de ellos, de los más duros, de los que no entienden, de los que son cabeza de concreto, que aunque les dé con una almádana, con un martillo, no les hace entender [...] ${ }^{23}$.

These modern examples, which start from very colloquial and popular registers, may show evidence of an old synonymy.

According to the documentation, the answer on what type or kind of martillo is an almádena can be found in the examples provided by CORDE from the 19th century in building highly specialized treaties:

1856, Metalurgia: Para la clasificación se hace uso de grandes cribas y de mazos y martillos de hierro; para la trituracion se ha empleado por mucho tiempo las machotas de hierro conocidas entre nosotros con los nombres de almaena ó almadena; pero hoy se hace uno casi exclusivamente de los cilindros trituradores ${ }^{24}$.

1892, Carreteras: La herramienta se reduce á un martillo ordinario de mango rígido ó montado en una vara flexible [...], Ilamándose en este último caso almadena de mango corto: el mazo no suele pesar más de un kilogramo²5.

In that way, the term of Arab origin has remained in the specific and specialized sector of construction: "las machotas de hierro conocidas entre nosotros". So that, almádena is defined as a type of hammer, with smaller dimensions ("de mango corto"), used to grind stones previously removed by hammers. Also, the mining treaties from the 18th and 19th centuries studied by Díez de Revenga and Puche Lorenzo (2005-2006: 85) confirm the existence and use of this specific type of hammer in the pointed sector ${ }^{26}$.

23 "They put red bones to the Syndic, the hardest, of those who are of concrete, it does not matter if I hit them with a sledgehammer, with a hammer, because they do not understand".

24 "For de classification, large screens and hammers and iron hammers are used, for the crushing ironed hammers have been used for a long time, known among us with the name of sledgehammer, but today crushing cylinders are the only thing used".

25 "The tool consists on an ordinary hammer with a rigid handle or with a flexible rod; in that case, the name of that tool is sledgehammer with a short handle".

26 There are many dictionaries and glossaries of mining technical lexicon that include almádena with similar definitions. For instance, in the Glosario de voces utilizadas por los mineros de Iberoamérica (1995) S.v. almadana the definition is: 'hammer about 5 or 10 kgs.'. Similar examples can be found in DHLE (1960-1996, s.v.). 
Tentatively, it is possible to mark that the Arabism almádena is subjected to a process of semantic specialization and it is part of the technical lexicon of construction and mining. Given the limited data that we have, probably, this word originally designated the same as martillo, but has come to designate a class or type of martillo (as a hyponym with respect to the hypernym martillo27).

However, it can be said that almádena could even disappear from these specialized areas, where ancient utensils and tools are objects that are no longer used and have been replaced by machines.

\section{Conclusions}

The voice of Arab origin almádena joined the Castilian in the late 13th century and came to designate a concept which there already was a Romance term for, martillo. It is not a lexical competition, since the Arabism is incorporated later than the Romance voice. However, it is possible to verify through documentation discussed in this article the semantic change ${ }^{28}$ for the Arabism almádena. In this case, the change consists on a restriction or semantic specialization, due to the fact that the Arabism almádena refers to a subclass or type of martillo in the world of construction. In a previous historical stage, almádena and martillo would have coexisted as synonyms. In that sense, it would be necessary to keep investigating in order to find more examples.

Also, the expansion of the Arab loanword almádena can be verified in other Spanish-speaking territories during the 16 th and 17 th centuries in comparison with what happens in the Peninsula.

Moreover, there are dialectal vestiges of this term in Andalucía: Garulo (1983: 186) located almaina in the ALEA (Atlas lingüístico y etnográfico de Andalucía) at certain points of Almería, Granada and Málaga. The given definition here is 'Macho, the main tool of the blacksmith with hitting the hot iron on the anvil' (map 974 in the ALEA), which is also related to the world of tools, specifically the smithy, and the meanings that have been explained. A lot of Arabisms, included almádena, have persisted in some areas of the ancient Kingdom of Granada dialectically, but have disappeared in the standard Spanish.

27 Therefore, it is a semantic change that consists on a restriction of meaning: a word takes on a new meaning in relation of subordination to another, i.e., a hyponym. It can also operate an extension of meaning, i.e., a word can acquire a superordination relationship relative to each other (a hypernym). For more information see Geeraerts (2010).

28 The semantic changes in Arab lexical borrowings are carefully studied by García González (2012) throughout the Middle Age and through the great work of Alfonso X the Learned (1993-1994, 1996). Often, a semantic restriction with its consequent specialization usually occurs in the specific fields of war and technology, as it happened in the case of almádena. 
In addition, this study would confirm the idea that Arabisms have been undergoing a process of semantic specialization that, in cases such as almádena, translates into a semantic restriction and a posterior specialization, due to the negative attitude towards this kind of lexicon developed since the late 15th century. Therefore, almádena should carry a specialization mark, which it currently lacks in the academic dictionary (DLE 2014, S.v.).

\section{References}

\subsection{Base corpus}

Gila Medina, Lázaro, 2000: Maestros de cantería y albañilería en la Granada moderna según los escribanos de la ciudad, Granada: Ilustre Colegio Notarial de Granada. (Can.Alb.)

De la Obra Sierra, Juan María, 2011: Correspondencia de Hernando de Zafra, Granada: Universidad de Granada. (HernandoZafra)

Galera MendozA, Esther, 2014: Arquitectos y maestros de obras en la Alhambra (siglos XVI-XVIII): artífices de cantería, albañilería yesería y forja, Granada: Comares. (Arquitectos)

\subsection{Control corpus}

Real Academia Española: Corpus diacrónico del español (CORDE) [http://www.rae.es].

\subsection{Bibliography}

Alonso, Ricardo, 1995: Glosario de voces utilizadas por los mineros de Iberoamérica, Madrid: CSIC.

Alvar, Manuel, 1961-1973: Atlas lingüístico y etnográfico de Andalucía (ALEA), Granada: Universidad de Granada-CSIC.

Álvarez de Miranda, Pedro, 2009: "Neología y pérdida léxica" in Elena de Miguel (coord.): Panorama de la lexicología, Barcelona: Ariel, 133-156.

Asensio, Eugenio, 1960: "La lengua compañera del imperio. Historia de una idea de Nebrija en España y Portugal”, Revista de Filología Española 53, 399-413.

BALDINGER, Kurt, 1985: “Lengua y cultura: su relación en lingüística histórica”, REL 15, 247-276.

Barrios Aguilera, Manuel, 2002: Granada morisca, la convivencia negada, Granada: Comares.

Boyd-Bowman, Peter, 2015 [2003-2007]: Léxico hispanoamericano 1493-1993, Hispanic Seminary of Medieval Studies: Universidad de Wisconsin [textred.spanport.wisc.edu]. 
Calderón Campos, Miguel, \& María Teresa García Godoy, 2015: Corpus diacrónico del español del reino de Granada. 1492-1833 (CORDEREGRA) [http://www.corderegra.es].

Cano Aguilar, Rafael, 2004: Historia de la Lengua Española, Barcelona: Ariel.

Corominas, Joan, \& José Antonio Pascual, 1980-1991: Diccionario crítico etimológico castellano e hispánico (DCECH), Madrid: Gredos.

CoRriente, Federico, 1977: A gramatical sketch of the Spanish-Arabic dialect bundle, Madrid: Instituto Hispano-Árabe de Cultura.

Corriente, Federico, 1999: Diccionario de arabismos y voces afines en iberorromance, Madrid: Gredos.

Corriente, Federico, 2004: "El elemento árabe en la historia lingüística peninsular" in Rafael Cano Aguilar (dir.): Historia de la lengua española, Barcelona: Ariel, 185-205.

Davies, Mark, 2016: El corpus del español (CdE) [http://www.corpusdelespañol.org].

Diez de Revenga, Pilar, \& Miguel Ángel Puche Lorenzo, 2005-2006: “La Colección de voces usadas en la minería, edición y estudio de un manuscrito anónimo del siglo XIX”, Revista de Lexicografía XII, 65-120.

Duboıs, Jean, 1962: Le vocabulaire politique et social en France de 1869 a 1872, París: Larousse.

Dworkin, Steven, 2004: “La transición léxica en el español bajomedieval” in Rafael Cano Aguilar (dir.): Historia de la lengua española, Barcelona: Ariel, 643-656.

Dworkin, Steven, 2006: “La naturaleza del cambio léxico” in José Luis Girón Alconchel \& José Jesús Bustos Tovar (coords.): Actas del VI Congreso Internacional de Historia de la Lengua Española, vol. I., Madrid: Arco/Libros, 67-84.

Dworkin, Steven, 2011: "La variación y el cambio léxico: algunas consideraciones" in Mónica Castillo Lunch \& Lola Pons Rodriguez (coords.): Así van las lenguas variando. Nuevas tendencias en la investigación del cambio lingüístico en español, Bern: Peter Lang, 155-168.

DworkIn, Steven, 2012: A history of Spanish Lexicon. A linguistic perspective, Oxford: Oxford University Press.

FASLA, Dalila, 2000: “La adopción de arabismos como fuente de creación sinonímica en español (datos para un estudio socio-semántico)", Anuario de lingüística hispánica 15-16, 83-100.

Gallego, María Ángeles, 2003: "The languages of Medieval Iberia and their religious dimension”, Medieval Encounters 9, 107-139. 
García Godor, Ma Teresa, 1999: El léxico del primer constitucionalismo español y mejicano (18101815), Granada: Universidad de Granada.

García Godoy, Ma Teresa, 2012: "La lengua de las primeras constituciones hispánicas: el cambio léxico-semántico” in Teresa Bastardín Martín \& Manuel Rivas Zancarrón (coords.): Actas del IX Congreso Internacional de Historia de la Lengua Española, Madrid/Frankfurt: Iberoamericana/ Vervuert, 107-132.

Garcia GonzÁlez, Javier, 1993-1994: "El contacto de dos lenguas: Ios arabismos en el español medieval y en la obra alfonsí", Cahiers de linguistique hispanique médiévale 18-19, 335-366.

García GonzÁlez, Javier, 1996: “Los préstamos árabes en el español: una revisión crítica” in Alegría Alonso Gonzalez (coord.): Actas del III Congreso Internacional de Historia de la Lengua, Madrid: Arco/Libros, 677-688.

Garcí Gonzalez, Javier, 2012: "Identidades y actitudes en el contacto entre el árabe y el español medieval y su reflejo en algunos cambios semánticos", e-Spania [http://e-spania.revues.org/21036].

GaRulo, Teresa, 1983: Los arabismos en el léxico andaluz (según los datos del Atlas Lingüístico y Etnográfico de Andalucía), Madrid: Instituto hispanoárabe de Cultura.

Geeraerts, Dirk, 2010: Theories of Lexical Semantics, Oxford, UK: Oxford University Press.

Giménez Eguibar, Patricia, 2011: Arabismos en el campo semántico de los oficios: de la competición léxica a la pérdida léxica, Wisconsin: University of Wisconsin.

Giménez Eguíbar, Patricia, 2015: "Dos casos de sustituciones léxicas: Ios arabismos alfayate y alfajeme” in Francisco Javier de Cos Ruiz \& Mariano Franco Figueroa (coords.): Actas del IX Congreso Internacional de Historia de la Lengua Española, Madrid/Frankfurt: Iberoamericana/ vervuert, $1413-1427$.

Giménez Eguibar, Patricia, 2016: "Attitudes toward Lexical Arabisms in 16th Century Spanish Texts" in Sandro Sessarego \& Fernando Tejero-Herrero (eds.): Spanish Language and Sociolinguistics Analysis, Amsterdam: John Benjamins, 363-380.

Giménez Eguíbar, Patricia, \& Daniel Waseserman Soler, 2011: "La Mala algarabía. Church. Monarchy and the Arabic Language in the 16th century Spain", The Medieval History Journal 14, 229- 258.

GuAdIx, Diego de, 2005 [1593]: Recopilación de algunos nombres arábigos que los árabes pusieron a algunas ciudades y otras muchas cosas, Elena Bajo Pérez \& Felipe Maíllo Salgado (eds.), Gijón: Trea. 
Harris-Northall, Ray, 1999: "Re-Latinization of Castilian lexis in the early sixteenth century", Bulletin of Híspanic Studies 76, 1-12.

LAPESA, Rafael, 1985: "Algunas consideraciones sobre el léxico político en los años de Larra y Espronceda" in Luis Rodriguez Zúñiga, María del Carmen Iglesias Cano \& Carlos Vicente Moya Valgañón (coords.): Homenaje a José Antonio Maravall, vol. 2, 393-414

LAPESA, Rafael, 1991: Historia de la lengua española, Madrid: Gredos.

Maíllo Salgado, Felipe, 1983: Los arabismos del castellano en la baja edad media: consideraciones históricas y filológicas, Salamanca: Universidad de Salamanca.

Matoré, Georges, 1953: La méthode en lexicologie. Domaine français, Paris: Marcel Didier.

MeILlet, Antoine, 1952: Linguistique historique et linguistique générale, París: Klincksiek.

Ortega Munilla, José, 1893: El Imparcial, Madrid: Hemeroteca Digital, Biblioteca Nacional del España.

Peinado Santaella, Rafael, 2017: Guerra santa, cruzada y yihad en Andalucía y en el reino de Granada (siglos XIII-XV), Granada: Universidad de Granada.

Real Academia Española, 1960-1996: Diccionario histórico de la lengua española [http://www.rae.es].

Real Academia Española, 2001: Nuevo Tesoro Lexicográfico de la Lengua Española (NTLLE), Madrid: Espasa-Calpe.

Real Academia Española, 2014: Diccionario de la lengua española, Madrid: Espasa-Calpe.

Stelger, Arnold, 1932: Contribución a la fonética del hispanoárabe y los arabismos en el íbero románico y siciliano, Madrid: CSIC.

Stelger, Arnold, 1967: "Arabismos" in Enciclopedia Lingüística Hispánica, vol. 2, 93-126.

WALSH, John, 1967: The Loss of Arabisms in the Spanish Lexicon (unpublished doctoral dissertation), Virginia: University of Virginia. 